\title{
M-Phase Inducer Phosphatase 2
}

National Cancer Institute

\section{Source}

National Cancer Institute. M-Phase Inducer Phosphatase 2. NCI Thesaurus. Code C104838.

M-phase inducer phosphatase 2 (580 aa, $\sim 65 \mathrm{kDa}$ ) is encoded by the human CDC25B gene. This protein plays a role in progression through the mitotic cell cycle. 